\title{
Gaucher's disease: a novel treatment and an important breakthrough
}

It is 110 years since Philippe Charles Ernest Gaucher first described the disease which bears his name. Successively over the intervening century the nature and extent of the lipid storage in the marrow and spleen have been defined (Beutler 1988); the osteopenic, lytic and osteonecrotic bone lesions have been described (Stowens et al 1985; Rosenthal et al 1989; Mankin et al 1990); the autosomal recessive mode of the genetic transmission of the disease has been delineated (Brady, Johnson and Uhlendorf 1971); and in 1965, a landmark discovery by Roscoe Brady and his co-workers proved that the disorder is caused by a specific enzyme deficit (Brady, Kanfer and Shapiro 1965). The enzyme, glucocerebroside hydrolase (beta-glucosidase), is responsible for breaking the glycoside bond fixing a glucose to a ceramide (sphingosine plus a fatty acid), a material released from cell membranes each time a cell dies. Without the release of the glucose molecule, the glucosylceramide cannot be excreted or reutilised but instead is stored in the lysosomal body of the macrophage and other cells of the reticuloendothelial system. The slow accumulation of these cells over the lifetime of a patient with type I Gaucher's disease is responsible for organomegaly, alterations in marrow physiology, deficits in blood factors (especially platelets), and structural bone changes, which often dominate the picture (Beutler 1988; Mankin et al 1990).

Orthopaedic surgeons are most often involved with this unhappy malady when patients develop complications. One of these is an acute, fulminant and exquisitely painful osteonecrosis of the medullary cavity and adjacent cortex of a long bone or the pelvis, the Gaucher 'crisis' (Bell, Mankin and Doppelt 1986; Yosipovitch and Katz 1990). Another is the fracture of a profoundly osteopenic vertebral body, or a bone of the appendicular skeleton as a result of a lytic lesion (Mankin et al 1990). The most common reason for referral, however, is when the patient becomes disabled by the development of corticocancellous osteonecrosis of the femoral or humeral head, or of the distal femur or proximal tibia (Amstutz 1973; Stowens et al 1985). The last-mentioned lesions are difficult to treat, responding hardly at all to conservative surgical

H. J. Mankin, MD, Edith M. Ashley Professor of Orthopaedics and Head of Department

Department of Orthopaedics, Massachusetts General Hospital, Fruit Street, Boston, Massachusetts 02114, USA

(C) 1993 British Editorial Society of Bone and Joint Surgery

$0301-620 X / 93 / 1562 \$ 2.00$

J Bone Joint Surg [Br] 1993; 75-B:2-3. procedures, and require joint replacement surgery in patients who are sometimes very young and active (Lachiewicz, Lane and Wilson 1981).

Until recently there has been no useful treatment for the underlying problem in Gaucher's disease. Exogenous administration of the deficient enzyme has been valueless, since it must act intracellularly to be effective. The accumulating glucosylceramide lies within the cell membrane, and indeed within the lysosomal body; early attempts at enzyme replacement with a beta-glucosidase failed for that reason. In a crucial experimental study, Barton et al in 1991 discovered that when the enzyme was altered to expose a mannose residue it was recognised by a lectin on the cell surface and could be transported across the cell membrane to become functional.

In the first studies, 12 non-splenectomised patients were given the mannose-terminated enzyme Ceredase (Genzyme Corporation, Cambridge, Massachusetts) intravenously at two-weekly intervals. Their platelet counts and haematocrits rose, and their acid phosphatase levels and splenic and hepatic volumes diminished, suggesting reversion to a more normal physiological state. The patients felt better and when enzyme treatment was continued for a year or more the stores of lipid melted from the spleen and liver and, presumably, from the bones. Current research is directed at determining the minimal dose and the appropriate frequency of administration of the enzyme, in an effort to reduce the expense of a therapy that currently is beyond the means of some of the patients (or for that matter, their insurance companies!).

The next phase of study will involve assessment of the bone changes to ascertain whether they also improve over time. Several clues suggest that they do. In one child, treated for more than two years, bone biopsies have shown a gradual return to normal histological appearance of the marrow, increased bone density and thickened cortices (Barton et al 1992). In the initial group of 12 patients there was improvement in the rate of ${ }^{133}$ xenon washout from the long bones, suggesting less sequestration in the marrow (McKusick et al; in press). MRI showed an increase in the marrow fat, strongly suggesting the substitution of normal fat for Gaucher's cells, and medullary haematopoiesis in response to the anaemia, leukopenia and thrombocytopenia characteristic of the disorder (Johnson et al 1992). The initial group of patients is being followed to assess the validity of these observations as well as the potential for improvement in bone density and diminution in frequency of fractures and 
bone infarctions. In addition, a study has begun to determine the effect of the enzyme on patients who have previously undergone splenectomy to ascertain if they respond differently.

The remarkable improvement achieved as a result of enzyme therapy is clearly a great breakthrough for patients with Gaucher's disease, but there are some additional spin-offs which may prove even more exciting and important. The gene locus for the deficient enzyme has been identified and the error in the nucleotide sequence defined (Ginns et al 1985; Hong et al 1990). Ginns and his co-workers have been successful in altering the genetic sequence in an animal and thus producing a classical, albeit very severe form of Gaucher's disease in a mouse (Tybulewicz et al 1992). It may not be long before gene-altering therapy can be used to treat this disease in man and provide a 'lasting' cure rather than the temporary relief afforded by administration of the presently available mannose-terminated enzyme (Choudary et al 1986).

Perhaps the greatest potential arising from the 'Ceredase Story' for Gaucher's disease, however, is the possibility that other metabolic diseases in which there

\section{REFERENCES}

Amstutz HC. The hip in Gaucher's disease. Clin Orthop 1973; 90:83-9.

Barton NW, Brady RO, Dambrosia JM, et al. Replacement therapy for inherited enzyme deficiency-macrophage-targeted glucocerebrosidase for Gaucher's disease. N Eng J Med 1991 ; 324:1464-70.

Barton NW, Brady RO, Dambrosia JM, et al. Dose-dependent responses to macrophage-targeted glucocerebrosidase in a child with Gaucher's disease. J Pediatr 1992; 120:277-80.

Bell RS, Mankin HJ, Doppelt SH. Osteomyelitis in Gaucher disease J Bone Joint Surg [Am] 1986; 68-A:1380-8.

Beutler E. Gaucher disease. Blood Rev 1988; 2:59-70.

Brady RO, Kanfer JN, Shapiro D. Metabolism of glucocerebrosides. II. Evidence of an enzymatic deficiency in Gaucher's disease. Biochem Biophys Res Commun 1965; 18:221-5.

Brady RO, Johnson WG, Uhlendorf BW. Identification of heterozygous carriers of lipid storage disease. Am J Med 1971; 51 :423-31.

Choudary PV, Tsuji S, Martin BM, et al. The molecular biology of Gaucher disease and the potential for gene therapy. Cold Spring Harbor Symp Quant Biol 1986; 51 :1047-52.

Ginns EI, Choudary PV, Tsuji S, et al. Gene mapping and leader polypeptide sequence of human glucocerebrosidase: implications for Gaucher disease. Proc Natl Acad Sci USA 1985; 82:7101-5.

Hong CM, Ohashi T, Yu XJ, Weiler S, Barranger JA. Sequence of two alleles responsible for Gaucher disease. DNA Cell Biol 1990; 9: 233-41 are severe skeletal abnormalities may also yield to the same type of management. Current research is pressing forward to discover the enzyme deficit, the gene locus, and the feasibility of enzyme replacement or gene alteration in patients with the mucopolysaccharidoses (including Hurler's, Hunter's and Morquio's diseases), thalassaemia, dysplasia epiphysealis multiplex, spondyloepiphyseal dysplasia, osteogenesis imperfecta, osteopetrosis and a host of other conditions.

We in orthopaedics, who have watched the suffering of children with these disorders and have been powerless to control the underlying processes, have been able to do little more than minimise the complications of their crippling deformities. We now find ourselves on the threshold of a great discovery, chemical 'cures' for diseases of the skeleton which, if started early enough, may allow the dwarfed to grow tall and weak bones to become strong. It is heady stuff, and difficult, perhaps, for the biochemically unsophisticated orthopaedic surgeon to comprehend, but clearly it is a major breakthrough which will soon alter our patients' world very much for the better.

HENRY J. MANKIN

Johnson LA, Hoppel BE, Gerard EL, et al. Quantitative chemical shift imaging of vertebral bone marrow in patients with Gaucher disease. Radiology 1992; 182:451-5.

Lachiewicz PF, Lane JM, Wilson PD Jr. Total hip replacement in Gaucher's disease. J Bone Joint Surg [Am] 1981; 63-A: 602-8.

Mankin HJ, Doppelt SH, Rosenberg AE, Barranger JA. Metabolic bone disease in patients with Gaucher's Disease. In: Avioli LV, Krane SM, eds. Metabolic bone disease. Philadelphia, etc: W. B. Saunders Co, 1990:730-52.

McKusick KA, Castoronovo FP, Strauss WW, et al. Inhaled Xenon-133 bone dynamics. In press.

Rosenthal DI, Mayo-Smith W, Goodsitt MM, Doppelt S, Mankin HJ. Bone and bone marrow changes in Gaucher disease : evaluation with quantitative CT. Radiology 1989; 170:143-6.

Stowens DW, Teitelbaum SL, Kahn AJ, Barranger JA. Skeletal complications of Gaucher disease. Medicine (Baltimore) 1985 64:310-22.

Tybulewicz VLJ, Tremblay ML, LaMarca ME, et al. Animal model of Gaucher's disease from targeted disruption of the mouse glucocerebrosidase gene. Nature 1992; 357:407-10.

Yosipovitch Z, Katz K. Bone crisis in Gaucher disease : an update. Isr J Med Sci 1990; $26: 593-5$. 